\title{
Effect of Different Shaking Systems on the Growth of Marine Diatom Phaeodactylum Tricornutum
}

\author{
Sevil D. Yakan Dundar ${ }^{1}$ (D, Oktay E. Tureyen ${ }^{1}$ (D)
}

Cite this article as: Yakan Dundar, S.D., \& Tureyen, O.E. (2021). Effect of different shaking systems on the growth of marine diatom Phaeodactylum Tricornutum. Aquatic Sciences and Engineering, 36(4), 207-214.

ORCID IDs of the author: S.D.Y.D. 0000-0003-2493-680X; O.T. $0000-0003-2346-1128$

'Department of Ocean Engineering, Istanbul Technical University, Istanbul, Turkey

Submitted: 30.03.2021

Revision Requested: 19.06.2021

Last Revision Received: 28.06.2021

Accepted:

10.07.2021

Online Published: 00.00 .0000

Correspondence: Oktay E. Tureyen

E-mail:

tureyen@itu.edu.tr

(C) Copyright 2021 The Author(s) Available online at

https://dergipark.org.tr/ase

\begin{abstract}
In aquatic ecosystems, the fact of encountering fluctuations is vital for the survival of phytoplankton, in terms of remaining in the euphotic zone and reaching the necessary nutrients for their growth. The existence and the abundance of the phytoplankton are also vital for the other living things in indirect or direct ways, due to being the fundamental components of the food chain and webs, in addition to their usage in several industries like fuel, pharmacy, or cosmetics. However, particularly for the energy industry, the production cost of biofuels by using phytoplankton is relatively higher than the cost of conventional fossil fuels. Thus, the need of increasing the phytoplankton biomass in artificial environments has emerged to reduce the biofuel production cost. For this purpose, the correlation of turbulence and growth rate has been investigated through various experimental studies. In addition to the previous studies, this study focuses on the turbulence effects at a small scale in respect of the movement directions. Fixed, axial, and orbital movements were performed and quantified in terms of the specific growth rate, doubling time and the productivity of biomass for each system. The frequencies of the axial and orbital systems were set to 40 and 80 rpm, respectively and the specific growth rates were quantified as $0.38,0.43$ and $0.42 \mu$ day ${ }^{-1}$ whereas the doubling times were calculated as $1.84,1.62$ and 1.63 day. In conclusion, it was observed that the frequency of the movement is more influential rather than the type of the movement.
\end{abstract}

Keywords: Marine diatom, Phaeodactylum tricornutum, shaking conditions, growth rate, algae cultivation

\section{INTRODUCTION}

Both fresh and marine aquatic ecosystems are sustained by the phytoplankton directly or indirectly due to its property of being the main element of the food chain and food web in these environments (Marra 1980). It is stated that almost half of the global primary productivity depends on the phytoplankton both in the areas of coastal and open ocean (Friend et al. 2009). In a shallow marine environment like coastal zones, the presence and the abundance of the phytoplankton are highly affected by the wind mixing; wind speed, and the prevailing wind direction (de Souza Cardoso and da Motta Marques 2009; Moreno-Ostos et al. 2009; Zhou et al. 2015). In the ocean, the interaction of the water surface with the ambient air temperature and the surface winds generate a mixing environment and turbulence that affects the physical parameters and the nutrient supply of the marine environment and consequently change the environmental conditions for the residing phytoplankton (Hemer et al. 2013a, b; Fan et al. 2013; Rumyantseva et al. 2015; Burns 2017). As seen, fortuitously oscillations of velocity in water flow, namely turbulence, can exist in all environments due to winds, tidal currents, or breaking winds with a broad range of turbulence dissipation rate changing from $10^{-2}$ to $10^{-10} \mathrm{~m}^{2} \mathrm{~s}^{-3}$. The smallest values of this range were stated as 
the result of the stratification in the water column in the oceans formed due to the weak near-surface wind mixing (Gargett 1989, 1997; MacKenzie et al. 1994; Johnson et al. 1994; Terray et al. 1996). Small-scale turbulence is mostly seen as the driving force of plankton trophodynamics (Saiz et al. 1992; MacKenzie et al. 1994) and interaction between the organisms and the surrounding particles (Rothschild and Osborn 1988). This condition is also pointed out with the different impacts of the large- and smallscale turbulent processes on the phytoplankton, individually or collectively. It was explained that individual physiology and population growth are directly altered by the large-scale turbulent processes, due to its impact on the primary physical factors like light, temperature, and nutrient availability, whereas only individuals are affected by the small-scale turbulent processes due to its scale of millimeters in terms of shear and strain forces (Sullivan and Swift 2003). The availability of nutrients directly affects the trophic state and community structure of the phytoplankton (Hecky and Kilham 1988). With the increase of turbulence, the diffusion boundary layer surrounding the phytoplankton cells decrease and a nutrient concentration boundary layer forms around the cells due to the rate difference of the absorption and diffusion processes which supports the uptake of the nutrients in the surrounding water and the removal of the photosynthetic wastes (Koch 1971; Jumars 1993; KarpBoss, L; Boss, E; Jumars 1996; Köhler 1997a; Barton et al. 2014). Moreover, the positive correlation of the small-scale turbulence and the growth rate has been observed in several experimental studies (Thomas and Gibson 1990; Beauvais et al. 2006; Mari and Robert 2008; Hondzo and Wüest 2009; Rokkan Iversen et al. 2010), specifically below the Kolmogorov length scale which states the length of the smallest turbulent eddies (Kolmogorov 1962), and in the estuarine incubation due to the sedimentation (Burns 2017).

Phytoplankton is one of the main players of global $\mathrm{CO}_{2}$ budget and aquatic ecosystems due to its capability of fixing around half of the global biogenic carbon (Field, C. B.; Behrenfeld, M. J.; Randerson 1998), its role in the mechanism of the biological pump (DeVries et al. 2012) and being an essential carbon source to aquatic food cycles (Köhler et al. 2018). Besides, phytoplankton has many uses in today's world in the field of nutritional source, prevention of environmental pollution, and fuel industry, in addition to their usage in cosmetics, pharmaceuticals, and aquaculture (Schenk et al. 2008; Mata et al. 2010; Makareviciene et al. 2011, 2013). Phytoplankton can be considered as an alternative source to renewable fuels due to its production potential as methane (Spolaore et al. 2006), electricity (Becker 1994), hydrogen (Ghirardi, M.L.; Zhang, J.P.; Lee, J.W.; Flynn, T.; Seibert, M.; Greenbaum, E.; Melis 2000) and biodiesel (Chisti 2007; Patil et al. 2008). Thus, increasing the biomass of the phytoplankton has been a current interest particularly for biodiesel production because the production cost is still much higher than the production of fossil fuels. Even though biodiesel from microalgae is much more environmentally friendly and contributes to the solution for global warming, the production cost is the barrier to overcome. The solution can be the increase of the biomass production, the increase of the microalgae lipid content under stress conditions, the combination of the water treatment process with the biofuel production or the increased number of the end prod- ucts while treating microalgae. For the optimization of the phytoplankton biomass increase in artificial environments, there are several factors to adjust such as light, temperature, $\mathrm{pH}$, dissolved oxygen, dissolved $\mathrm{CO}_{2}$, photosynthesis rate, nutrient and turbulence as a result of mixing (Fernández et al. 2012; Lucker et al. 2014; Shriwastav et al. 2017). Productivity of the phytoplankton and its relation with the ambient turbulence intensity in natural waters has been shown in many studies (Hondzo and Lyn 1999; Zhong 2004; Hondzo and Al-Homoud 2007; Wang et al. 2016). It has been also stated that mixing has many impacts on the production of phytoplankton such as transporting them by advection between the light and dark conditions, intensifying the air-water interface interaction in terms of dissolved oxygen and carbon, enhancing the nutrient transfer as a result of decrement on the boundary layers around the cells and providing them to stay in the water column as suspended material (Marshall and Huang 2010).

Taking into account the turbulent pulsation for the phytoplankton productivity, it is stated that moderate turbulent pulsation with frequencies of 0.5 and $1.0 \mathrm{~Hz}$ displays better results in terms of biomass quantity (San et al. 2017). On the contrary, the same study expresses that strong turbulent pulsation with a frequency of $1.5 \mathrm{~Hz}$ or more, conduce to lower biomass than stationary conditions by damaging the cells and reducing the growth rate of the phytoplankton. It is also stated that immoderate turbulence causes phytoplankton cell damages (Thomas and Gibson 1990; Bałdyga and Pohorecki 1998) and consequently a decrement in the growth rate (Marshall and Huang 2010). The quantification of the growth rate is a required step of monitoring the increase of phytoplankton cultivation and, counting the cells, measuring the optical density and determination of chemicals can be given as examples of the quantitative methods (Caspers 1970; Schwartz 1975; Hallegraeff 1977). Altering in the number of cells (Rhee and Gotham 1981; Kagami and Urabe 2001) or chlorophyll pigment (Bienfang and Takahashi 1983; Landry et al. 1995; Calbet and Landry 2004) has been considered as the indicator of the growth rate.

Cultivation of the phytoplankton is mostly performed in batch cultures which can be defined as enclosed circuits with finite volume and nutrient sources that will eventually encounter the diverse limiting factors (Barsanti and Gualtieri 2014). Thus, cultivation of the phytoplankton needs mixing to provide a homogeneous medium in terms of nutrient, light, temperature, and gas exchange distribution and to prevent the sedimentation of the organisms. It is remarked that the growth of the phytoplankton is affected by the parameters such as mixing, light intensity, and $\mathrm{CO}_{2}$ concentration (Sforza et al. 2012), and the biomass production of the phytoplankton increases with efficient mixing due to the frequent exposure of the cells with essential nutrients and necessary physical parameters like light (Kunjapur and Eldridge 2010). A way to provide a small-scale mixing medium is continuous shaking the cultivation flasks (Barsanti and Gualtieri 2014). Thus, shaking the flasks also provides aeration which potentially increases the growth rate of phytoplankton due to the efficient uptake of nutrients and proper illumination medium following the increase of the photosynthesis process (Zhao et al. 2011). Diverse methods are used for the cultivation of phytoplankton in 
flasks, for example, manual mixing once or twice a day (Makareviciene et al. 2011), mixing with the help of a shaker (Han et al. 2012) or through aeration (Barsanti and Gualtieri 2014). The positive effect of aeration on the growth rate of phytoplankton is shown through the experimental studies consisting of three different treatments; aeration, manual shake, and no shake (Harun et al. 2018). It is also shown through the experimental studies that shaking and aeration are efficient parameters of the phytoplankton cultivation in order to increase biomass productivity and concentration due to their impacts on the light intensity and $\mathrm{CO}_{2}$ concentration (Vanags et al. 2015). Another experimental study which compares the effects of still and turbulent conditions has concluded that the growth rates of the phytoplankton are higher in turbulent waters than in still waters, independently of the phytoplankton size. In the same experimental study, an orbital shaker table oscillating with a velocity of $130 \mathrm{rpm}$ has been used to form turbulent conditions. As a result, they add that the reason of this fact is due to the slowness of the nutrient flux towards the cells whereas the flux increases under turbulent conditions, and consequently increases the opportunity of absorbing nutrients and the growth rate of the phytoplankton cells (Peters et al. 2006). In the light of these information, this study is aimed to investigate the effect of three different shaking conditions on the growth rate of a marine diatom, P. tricornutum.

\section{MATERIALS AND METHODS}

\begin{abstract}
Algae cultivation
Seawater from the upper layer of Tarabya coast in the Istanbul Strait with approximately 17-18 psu was collected for algae medium and filtered with active carbon and filters of different pore sizes Whatman ${ }^{\text {TM }}$ GF6 filter and 0.45 um pore sized Sartorius cellulose nitrate filter, respectively. Totally 12 flasks, with four parallels for each system, were filled with $400 \mathrm{~mL}$ modified f/2 nutrient solution, the conventional nutrient mixture of diatoms, which is given in Table 1 (Guillard and Ryther 1962; Hao et al. 2020). The temperature of the incubation environment was set about $21 \pm 1^{\circ} \mathrm{C}$ in a temperature-controlled room under a continuous light intensity of about 3150-3200 lux. Prior to the experiment, the diatom species $P$. tircornutum of approximately $10 \mu \mathrm{m}$ length, has been kept in the same temperature-controlled room under continuous light intensity, and the cultivation was performed using the batch of the species in exponential growth phase.
\end{abstract}

Table 1. Modified f/2 medium for microalgae cultivation.

\begin{tabular}{|c|c|}
\hline Chemical & Concentration (mg L-1 seawater) \\
\hline $\mathrm{NaNO}_{3}$ & 75 \\
\hline $\mathrm{NaH}_{2} \mathrm{PO}_{4} \cdot \mathrm{H}_{2} \mathrm{O}$ & 5 \\
\hline $\mathrm{Na}_{2} \mathrm{SiO}_{3} .5 \mathrm{H}_{2} \mathrm{O}$ & 12.9 \\
\hline $\mathrm{CuSO} \cdot 5 \mathrm{H}_{2} \mathrm{O}$ & 0.005 \\
\hline $\mathrm{ZnSO}_{4} \cdot 7 \mathrm{H}_{2} \mathrm{O}$ & 0.011 \\
\hline $\mathrm{CoCl}_{2} \cdot 6 \mathrm{H}_{2} \mathrm{O}$ & 0.005 \\
\hline $\mathrm{MnCl}_{2} \cdot 4 \mathrm{H}_{2} \mathrm{O}$ & 0.090 \\
\hline $\mathrm{FeCl}_{3} \cdot 6 \mathrm{H}_{2} \mathrm{O}$ & 0.909 \\
\hline
\end{tabular}

\section{Experimental setup}

The experiment was set on three different conditions: Manual shaking, once vigorous shaking by hand every day, and constant automatic shaking with axial, $80 \mathrm{rpm}$, and orbital, $40 \mathrm{rpm}$, movements. The frequencies of the systems were selected as stated because the movements of the systems were almost identical with these frequencies. Orbital and axial movements were provided by ISOLAB 3D Shaker and IKA HS 260 Horizontal Shaker, respectively.

\section{Analyzing data}

During the experiment, cell numbers were quantified by means of Beckman Coulter Z2 Coulter ${ }^{\circledR}$ Particle Count and Size Analyzer, and the fluorescence intensity of the cells were measured by using PerkinElmer LS- 55 fluorescence spectrophotometer. Cell numbers were utilized to measure the rate of the diatom growth and the productivity of the diatom biomass over time and chlorophyll-a measurements with fluorescence spectrophotometer were used to control the correction of the cell number measurements. The wavelengths of excitation and emission were adjusted as $430 \mathrm{~nm}$ and $663 \mathrm{~nm}$ respectively for chlorophyll-a pigment (Yentsch and Menzel 1963). The measurements were performed for 26 days. All measurements that are given as results are the averages of 4 parallels mentioned in the methods section.

All the graphs were plotted and the statistical analysis was performed with SigmaPlot. In addition to the graphical representation of the growth, numerical calculations were performed to quantify the specific growth rate, doubling time and biomass productivity of each system by using the data of the log phase in the equations of 1,2 , and 3, respectively with the representation of cell density and time by $\mathrm{N}$ and $\mathrm{t}$ (Issarapayup et al. 2009; Wang et al. 2010; Asmare et al. 2013; Zhu et al. 2013; Komolafe et al. 2014; Harun et al. 2018).

Specific growth rate $\left(\mathrm{u} \mathrm{day}^{-1}\right)=\frac{\ln \left(N_{2} / N_{1}\right)}{t_{2}-t_{1}}$

Doubling time $($ day $)=\frac{\ln 2}{\text { specific growth rate }}$

Biomass productivity $=\frac{N_{2}-N_{1}}{t_{2}-t_{1}}$

\section{RESULTS AND DISCUSSION}

First of all, the obtained results will be given for each type of movement separately, then they will be compared with each other in the context of the growth rate of the selected diatom. For each type of movement, the change of cell numbers and fluorescence intensity over time were counted and measured during the whole experiment period. Fluorescence intensity is considered as the indicator of vitality due to its decreasing intensity level in senescent cells (Gielen et al., 2007; Subhash, Wenzel, \& Lichtenthaler, 1999). On the other hand, any discrimination like that cannot be achieved by counting the cell numbers with the instrument used in the experiment. That could be the reason for seeing possible correlation differences of the two measuring methods towards the end of the experiment. 
The first type of movement which is still and has no constant velocity or motion was chosen as the control system of the whole experiment. The increase in the cell numbers and the fluorescence intensity during the experiment period is given in Figure 1. It is seen that the diatom culture is in the lag phase of its growth in the time of the first two days of the experiment. This lag phase is followed by the log phase which represents the exponential increase of the cell numbers. The log phase continues about a week, and then the rate of the growth lessens its effect, meaning that the log phase is followed by a declining growth rate for a few days. About 12 days later, the stationary phase is reached. Correlatively, the change in the fluorescence intensity during the experiment period follows the same trend of the cell numbers. The declining trend observed during the last days of the experiment is probably because of the death of the cells, therefore it can be said that after about 22 days, the death phase arises. This trendline difference in the cell number and the fluorescence intensity is possibly due to the difference in the two measurement methods as mentioned before.

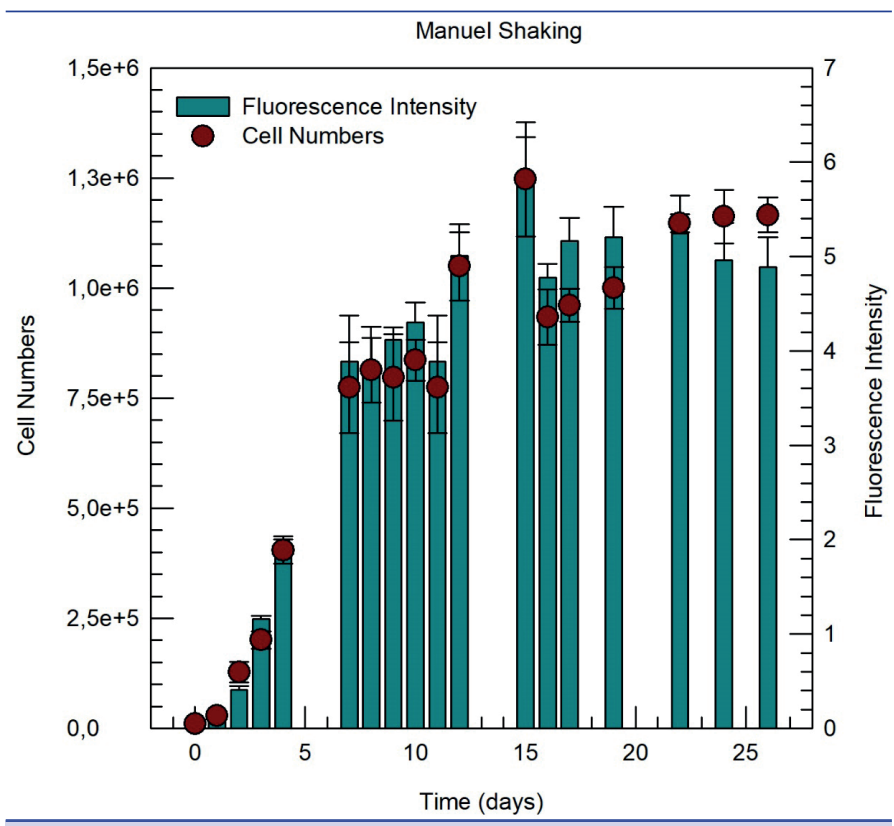

Figure 1. The growth trend of Phaeodactylum tricornutum with manual shaking during a 26-day experiment period, by means of the average cell number and fluorescence intensity of 4 parallels.

The second type of movement was axial shaking with a frequency of $80 \mathrm{rpm}$. Similar to the findings shown in Figure 1, the increase of the cell numbers and the fluorescence intensity in the axial shaking system is given in Figure 2. The first two days show a similar pattern with the control system and are considered as the lag phase, which is followed by the log phase until the $9^{\text {th }}$ day. Then the growth slope declines gradually and a stationary phase is reached on the $17^{\text {th }}$ day.

The third type of movement was 3D orbital shaking with a frequency of $40 \mathrm{rpm}$. Although it seems that there is a numerical difference in the shaking frequency of the axial and orbital shakers,

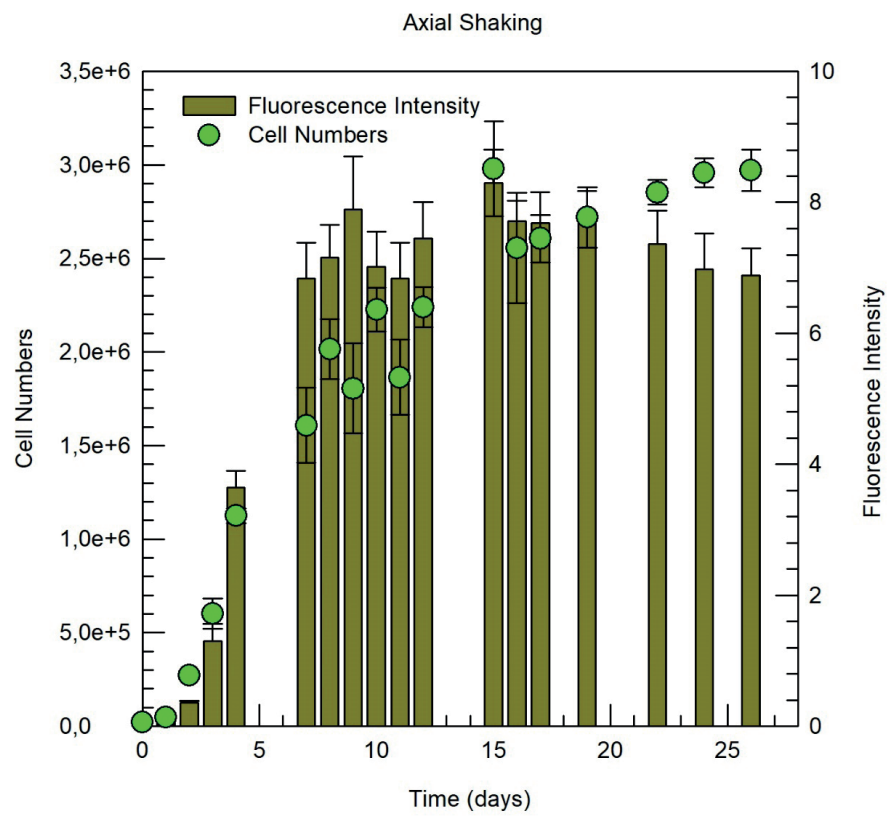

Figure 2. The growth trend of Phaeodactylum tricornutum in an axial shaking environment with a frequency of 80 rpm during a 26-day experiment period, by means of the average cell number and fluorescence intensity of 4 parallels.

these frequencies were chosen to equalize the shaking impact on the flasks as mentioned before. The variation of the cell numbers and the fluorescence intensity in the orbital shaking system is plotted with respect to the experiment duration and is shown

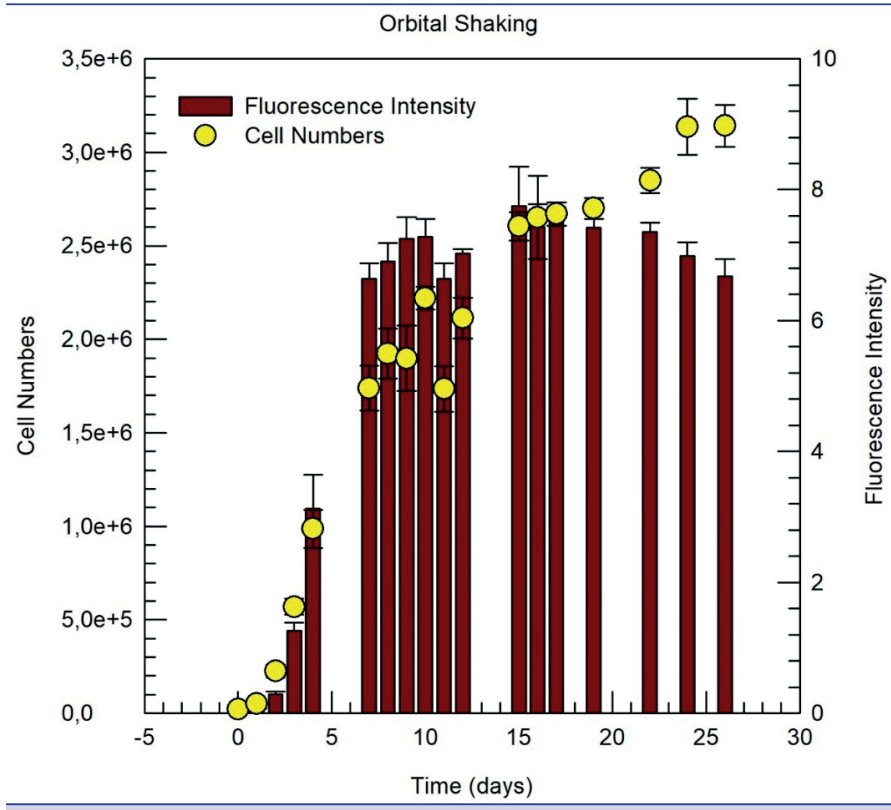

Figure 3. The growth trend of Phaeodactylum tricornutum in an orbital shaking environment with a frequency of 40 rpm during a 26-day experiment period, by means of the average cell number and fluorescence intensity of 4 parallels. 
in Figure 3. Again, the first two days show a similar pattern with the control system and are named as the lag phase. Then it is followed by the log phase until the $12^{\text {th }}$ day. Later, a gradual decline is observed until the $16^{\text {th }}$ day, and then the stationary phase is reached.

After separate observations of each type of movement and their impact on cell growth, an overview of the systems in terms of cell number and fluorescence intensity will be useful. Therefore, a comparison of the observations is seen in Figure 4. For all of the systems, the lag phase seems identical for the first two days. After the lag phase, a log phase with almost the same increasing slope is seen for the first 10 days of the experiment duration. Later, the separation of the systems emerges, this case is obvious especially for the still system. Although all the systems show a similar pattern, the cell numbers in the still system reach the stationary phase at a lower level. This separation and level difference are also apparent in fluorescence intensity measurements shown in Figure 4(b), in addition to the early separation of the still system seen in the log phase.

The positive correlation between the cell number and the fluorescence intensity, which can also be named as optical density, has been previously stated in several studies for decades (Toennies and Gallant 1949; Butterwick et al. 1982; Sandnes et al. 2006; Myers et al. 2013; Sivakumar, R; Rajendran 2013), in addition to the usage of optical density as an indirect measure of the growth (Harun et al. 2018). Thus, the parallelism in the trends of the two measuring methods is normally expected in the present study.

Specific growth rate, doubling time, and biomass productivity of each system were calculated from the data of cell numbers and given in Table 2. The inverse ratio of the specific growth rate and the doubling time is apparent due to the nature of their formulizations as given in Eq. 1 and 2. Rapidly growing cells represent a lower doubling time and vice versa. The calculations of Eq. 1, 2, and 3 were performed taking into account the interval between the first and the $10^{\text {th }}$ days. The reason for choosing this period is its correspondence to the log phase for each type of movement.

The results point out the effectiveness of shaking, independent of its type, whether the movement is in the axial or orbital direction. Previous studies also emphasize the difference of shaking type by quantifying the rate of the phytoplankton growth as 0.26 and $0.23 \mu$ day $^{-1}$ for the manual and no shake treatments, respectively (Harun et al. 2018). Except for discrete manual movement, the growth rates of the cells subjected to continuous vertical

Table 2. The rate of the specific growth $\left(\mu\right.$ day $\left.^{-1}\right)$, doubling time (day) and the productivity of the biomass of still, axial, and orbital type of movement (average of 4 parallels).

\begin{tabular}{lccc}
\hline & $\begin{array}{c}\text { Specific growth } \\
\text { rate }\left(\boldsymbol{\mu} \text { day }^{-1}\right)\end{array}$ & $\begin{array}{c}\text { Doubling } \\
\text { time (day) }\end{array}$ & $\begin{array}{c}\text { Biomass } \\
\text { productivity } \\
\text { (cell day }^{-1} \text { ) }\end{array}$ \\
\hline Fixed & 0.38 & 1.84 & 184557 \\
Axial & 0.43 & 1.62 & 249024 \\
Orbital & 0.42 & 1.63 & 248092
\end{tabular}
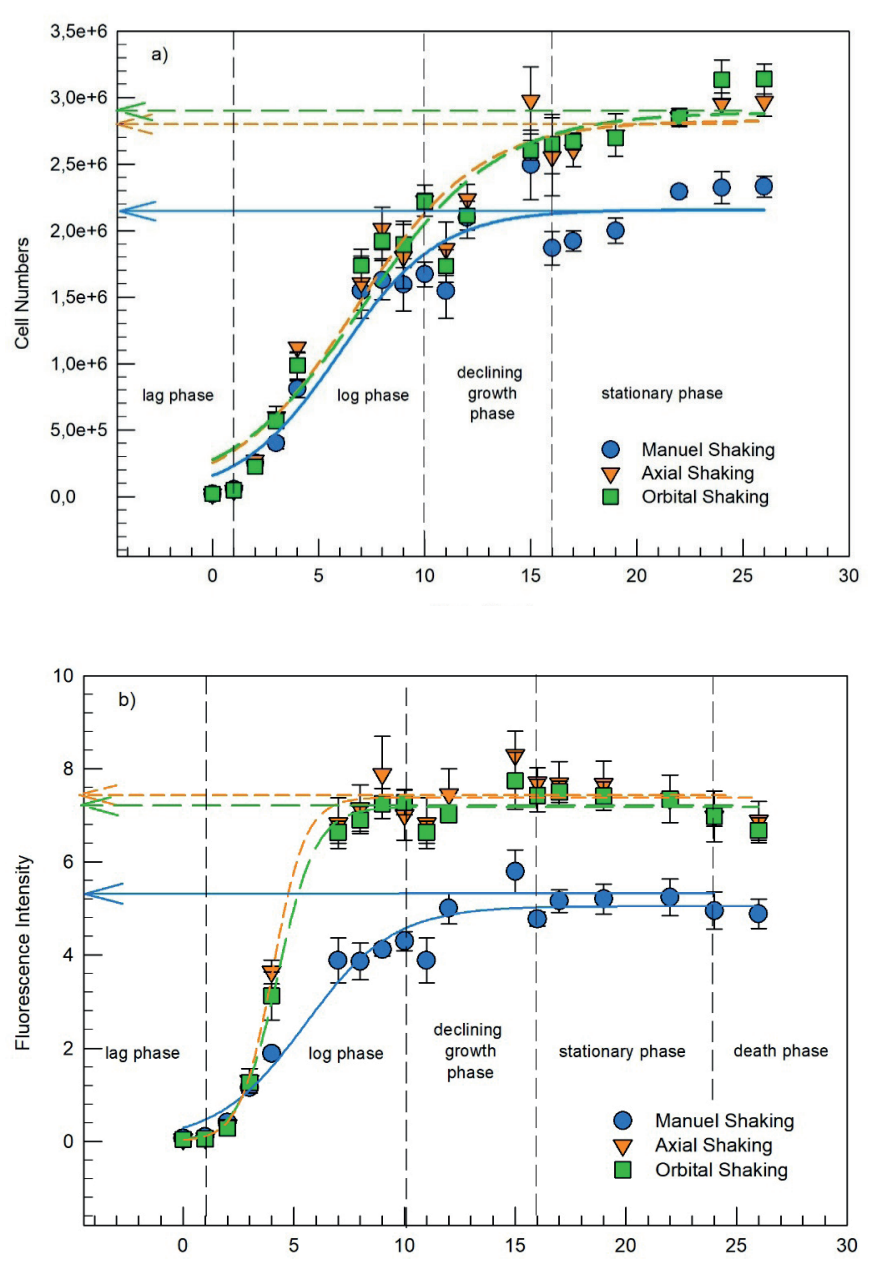

Figure 4. The trend of Phaeodactylum tricornutum growth in three types of movement; still, axial and orbital shaking from the perspective of a) cell number b) fluorescence intensity (average of 4 parallels).

movements with the frequencies of $2,1.5$, and $1 \mathrm{~Hz}$, corresponding to 120,90 , and $60 \mathrm{rpm}$, the growth rates were observed to be varying according to the species. In detail, the findings can be summarized as shown in Table 3 (Burns 2017).

Although the species used in the present study is a marine diatom, it is worth mentioning a previous study that is about the effects of small-scale turbulence on the growth rates of ten different flagellates. The experimental observations of the study emphasize that the degree of the turbulence can show insignificant change, a reduction, or an increase in the net growth rate. The authors conclude that this variation of the effect of turbulence in the growth rate highly depends on the physical parameters such as the degree of light, nutrients, or temperature in addition to the phytoplankton species (Sullivan and Swift 2003). In addition, a mean growth rate of 0.42 day $^{-1}$ was measured in a field study performed in the adjacent mainstream of River Severn in the UK for a composition of chlorophytes, centric diatoms, pennate diatoms, and cryptophytes (Köhler 1997b)therefore natural mixing conditions should be simulated as closely as possible during the 
Table 3. The growth rates of phytoplankton species changing with different frequencies (Burns, 2017).

\begin{tabular}{lccc}
\hline Species & $\begin{array}{c}\text { Cell length } \\
(\mu \mathrm{m})\end{array}$ & $\begin{array}{c}\text { Growth rate } \\
(\text { day-1) }\end{array}$ & $\begin{array}{c}\text { Frequency } \\
(\mathbf{H z})\end{array}$ \\
\hline Thalassiosira & $18-20$ & 0.38 & 2 \\
Thalassiosira & $18-20$ & 0.41 & 1.5 \\
Thalassiosira & $18-20$ & 0.42 & 1 \\
Chaetocero & $14-16$ & 0.97 & 2 \\
$\begin{array}{l}\text { Chaetocero } \\
\text { Thalassiosira }\end{array}$ & $14-16$ & 0.94 & 1 \\
$\begin{array}{l}\text { pseudonana } \\
\text { Thalassiosira }\end{array}$ & $6-8$ & 1.02 & 2 \\
$\begin{array}{l}\text { pseudonana } \\
\text { Thalassiosira }\end{array}$ & $6-8$ & 1.02 & 1 \\
$\begin{array}{l}\text { pseudonana } \\
\text { Phaeocystis } \\
\text { globosa }\end{array}$ & $6-8$ & 0.99 & 0.5 \\
$\begin{array}{l}\text { Phaeocystis } \\
\text { globosa }\end{array}$ & $4-7$ & 0.79 & 2 \\
$\begin{array}{l}\text { Phaeocystis } \\
\text { globosa }\end{array}$ & $4-7$ & 0.8 & 1 \\
\end{tabular}

incubation. A new device is described here which combines the advantages of a dialysis chamber with a programmable vertical mixing regime. Realistic phytoplankton growth rates can thus be measured in situ under conditions of vertical mixing and smallscale turbulence. The chamber made of transparent, UV-transmitting acrylic glass was fitted at both ends with permeable polycarbonate membranes. It was moved vertically through the water column by a pocket-sized lift and rotated simulataneously on its central axis. The method was applied to two types of experiments on growth and losses of phytoplankton in the River Severn, UK. The first one compared changes in biovolume of phytoplankton in a water parcel flowing downstream ( $6 \% \mathrm{~h}^{-1}$ decline). Taking into consideration all these findings, a remarkable point of the present study can be put forward as the frequency of the movement is more influential on the growth characteristics rather than the type of movement. Thus, the observed data of the axial and orbital types of movements that are close to each other seems reasonable.

\section{CONCLUSION}

An experimental study with a duration of 26 days was performed to observe the outcomes of the turbulence on a small scale in the context of the growth process of $P$. tricornutum. Three separate movement systems were set in a temperature-controlled and well-lighted room for the incubation of the selected diatom phytoplankton species. These were fixed, axial, and orbital shaking systems with four replicates of each. Two measurement methods were utilized to follow the growth trend of the species; cell counting and optical density (fluorescence intensity). The fixed system with no constant motion gave rise to lower growth rates compared with the other dynamic systems, as expected. The frequency of the axial and orbital systems was set almost at the same rate by checking visually, and the growth rate of the axial and orbital shak- ing systems was observed similarly. Therefore, it is concluded that the frequency of the turbulence on a small scale is more impactful on the rate of the phytoplankton growth rather than the direction of the turbulence source. Optimization of the biomass production of the microalgae is a highly focused topic because replacement of the fossil fuels by biodiesel from microalgae is still not feasible because of the high production cost. Presented study and further studies may contribute to the advancement in this field to increase biomass production while reducing production costs.

Acknowledgment: The experimental study was performed during the undergraduate degree thesis work of Erdinç Kara in the Ecotoxicology Research and Education Laboratory of the Faculty of Naval Architecture and Ocean Engineering at Istanbul Technical University. Oktay Eren Tureyen proposed the problem, Sevil Deniz Yakan prepared the manuscript draft and both of the authors contributed to the design and writing of the manuscript as well as the set-up and the implementation of the experiments. The authors declare no financial, commercial, and legal conflict of interest.

Data Set Statement: The datasets generated and analysed during the current study are available from the corresponding author on reasonable request.

Conflict of interests: The authors declare that they have no conflict of interest.

\section{Ethics committee approval: -}

\section{Funding: -}

\section{Acknowledgements: -}

\section{Disclosure: -}

\section{References}

Asmare AM, Demessie BA, Murthy GS (2013) Baseline Study on the Dairy Wastewater Treatment Performance and Microalgae Biomass Productivity of an Open Pond Pilot Plant: Ethiopian Case. J Algal Biomass Util 4:88-109.

Bałdyga J, Pohorecki R (1998) Influence of Turbulent Mechanical Stresses on Microorganisms. Appl Mech Rev 51:121-140. [CrossRef]

Barsanti L, Gualtieri P (2014) Algae. CRC Press.

Barton AD, Ward BA, Williams RG, Follows MJ (2014) The impact of finescale turbulence on phytoplankton community structure. Limnol Oceanogr Fluids Environ 4:34-49. [CrossRef]

Beauvais S, Pedrotti M, Egge J, et al (2006) Effects of turbulence on TEP dynamics under contrasting nutrient conditions: implications for aggregation and sedimentation processes. Mar Ecol Prog Ser 323:47-57. [CrossRef]

Becker EW (1994) Microalgae: Biotechnology and Microbiology. Cambridge University Press, Cambridge.

Bienfang PK, Takahashi M (1983) Ultraplankton growth rates in a subtropical ecosystem. Mar Biol 76:213-218. [CrossRef]

Burns, Wilton Gray, "Effects of small-scale turbulence on phytoplankton growth and metabolism" (2017). Master's Theses and Capstones. 1113. [CrossRef]

Butterwick C, Heaney SI, Talling JF (1982) A comparison of eight methods for estimating the biomass and growth of planktonic algae. Br Phycol J 17:69-79. [CrossRef] 
Calbet A, Landry MR (2004) Phytoplankton growth, microzooplankton grazing, and carbon cycling in marine systems. Limnol Oceanogr 49:51-57. [CrossRef]

Caspers H (1970) J. D. H. Strickland and T. R. Parsons: A Practical Handbook of Seawater Analysis. Ottawa: Fisheries Research Board of Canada, Bulletin 167, 1968. 293 pp. \$ 7.50. Int Rev der gesamten Hydrobiol und Hydrogr 55:167-167. [CrossRef]

Chisti Y (2007) Biodiesel from microalgae. Biotechnol Adv 25:294-306. [CrossRef]

de Souza Cardoso L, da Motta Marques D (2009) Hydrodynamics-driven plankton community in a shallow lake. Aquat Ecol 43:73-84. [CrossRef]

DeVries T, Primeau F, Deutsch C (2012) The sequestration efficiency of the biological pump. Geophys Res Lett 39:n/a-n/a. [CrossRef]

Fan Y, Held IM, Lin S-J, Wang XL (2013) Ocean Warming Effect on Surface Gravity Wave Climate Change for the End of the Twenty-First Century. J Clim 26:6046-6066. [CrossRef]

Fernández I, Acién FG, Fernández JM, et al (2012) Dynamic model of microalgal production in tubular photobioreactors. Bioresour Technol 126:172-181. [CrossRef]

Field, C. B.; Behrenfeld, M. J.; Randerson JT ;Falkowsk. P (1998) Primary Production of the Biosphere: Integrating Terrestrial and Oceanic Components. Science (80- ) 281:237-240. [CrossRef]

Friend AD, Geider RJ, Behrenfeld MJ, Still CJ (2009) Photosynthesis in Global-Scale Models. In: Marine Ecology Progress Series. pp 465497 [CrossRef]

Gargett AE (1989) Ocean Turbulence. Annu Rev Fluid Mech 21:419-451. [CrossRef]

Gargett AE (1997) "Theories" and techniques for observing turbulence in the ocean euphotic zone. Sci Mar 61:25-45

Ghirardi, M.L.; Zhang, J.P.; Lee, J.W.; Flynn, T.; Seibert, M.; Greenbaum, E.; Melis A (2000) Microalgae: a green source of renewable $\mathrm{H} 2$. Trends Biotechnol 18:506-511. [CrossRef]

Gielen B, Löw M, Deckmyn G, et al (2007) Chronic ozone exposure affects leaf senescence of adult beech trees: A chlorophyll fluorescence approach. J Exp Bot 58:785-795. [CrossRef]

Guillard RRL, Ryther JH (1962) Studies of Marine Planktonic Diatoms: I. Cyclotella nana Hustedt, and Detonula Confervacea (Cleve) Gran. Can J Microbiol 8:229-239. [CrossRef]

Hallegraeff GM (1977) A comparison of different methods used for the quantitative evaluation of biomass of freshwater phytoplankton. Hydrobiologia 55:145-165. [CrossRef]

Han W, Li C, Miao X, Yu G (2012) A Novel Miniature Culture System to Screen CO2-Sequestering Microalgae. Energies 5:4372-4389. [CrossRef]

Hao T Bin, Yang YF, Balamurugan S, et al (2020) Enrichment of f/2 medium hyperaccumulates biomass and bioactive compounds in the diatom Phaeodactylum tricornutum. Algal Res 47:101872. [CrossRef]

Harun, M., Peralta, H. M. M., Gonawan, N. H., \& Shahri, Z. (2018). Effect of Mixing on the Density and Chlorophyll A Content on Botryococcus Sp. Journal of Science and Technology, 10(2). [CrossRef]

Hecky RE, Kilham P (1988) Nutrient limitation of phytoplankton in freshwater and marine environments: A review of recent evidence on the effects of enrichment1. Limnol Oceanogr 33:796-822. [CrossRef]

Hemer MA, Fan Y, Mori N, et al (2013a) Projected changes in wave climate from a multi-model ensemble. Nat Clim Chang 3:471-476. [CrossRef]

Hemer MA, Katzfey J, Trenham CE (2013b) Global dynamical projections of surface ocean wave climate for a future high greenhouse gas emission scenario. Ocean Model 70:221-245. [CrossRef]

Hondzo M, Al-Homoud A (2007) Model development and verification for mass transport to Escherichia coli cells in a turbulent flow. Water Resour Res 43:. [CrossRef]

Hondzo M, Lyn D (1999) Quantified small-scale turbulence inhibits the growth of a green alga. Freshw Biol 41:51-61. [CrossRef]
Hondzo M, Wüest A (2009) Do Microscopic Organisms Feel Turbulent Flows? Environ Sci Technol 43:764-768. [CrossRef]

Issarapayup K, Powtongsook S, Pavasant P (2009) Flat panel airlift photobioreactors for cultivation of vegetative cells of microalga Haematococcus pluvialis. J Biotechnol 142:227-232. [CrossRef]

Johnson GC, Lueck RG, Sanford TB (1994) Stress on the Mediterranean Outflow Plume: Part II. Turbulent Dissipation and Shear Measurements. J Phys Oceanogr 24:2084-2092. [CrossRef]

Jumars PA (1993) Concepts in biological oceanography. Oxford University Press

Kagami M, Urabe J (2001) Phytoplankton growth rate as a function of cell size: An experimental test in Lake Biwa. Limnology 2:111-117. [CrossRef]

KarpBoss, L; Boss, E; Jumars P (1996) Nutrient fluxes to planktonic osmotrophs in the presence of fluid motion. In: Oceanography and Marine Biology. pp 71-107

Koch AL (1971) The Adaptive Responses of Escherichia coli to a Feast and Famine Existence. pp 147-217. [CrossRef]

Köhler J (1997a) Measurement of in situ growth rates of phytoplankton under conditions of simulated turbulence. J Plankton Res 19:849862. [CrossRef]

Köhler J (1997b) Measurement of in situ growth rates of phytoplankton under conditions of simulated turbulence. J Plankton Res 19:849862. [CrossRef]

Köhler J, Wang L, Guislain A, Shatwell T (2018) Influence of vertical mixing on light-dependency of phytoplankton growth. Limnol Oceanogr 63:1156-1167. [CrossRef]

Kolmogorov AN (1962) A refinement of previous hypotheses concerning the local structure of turbulence in a viscous incompressible fluid at high Reynolds number. J Fluid Mech 13:82-85. [CrossRef]

Komolafe O, Velasquez Orta SB, Monje-Ramirez I, et al (2014) Biodiesel production from indigenous microalgae grown in wastewater. Bioresour Technol 154:297-304. [CrossRef]

Kunjapur AM, Eldridge RB (2010) Photobioreactor Design for Commercial Biofuel Production from Microalgae. Ind Eng Chem Res 49:35163526. [CrossRef]

Landry M, Kirshtein J, Constantinou J (1995) A refined dilution technique for measuring the community grazing impact of microzooplankton, with experimental tests in the central equatorial Pacific. Mar Ecol Prog Ser 120:53-63. [CrossRef]

Lucker BF, Hall CC, Zegarac R, Kramer DM (2014) The environmental photobioreactor (ePBR): An algal culturing platform for simulating dynamic natural environments. Algal Res 6:242-249. [CrossRef]

MacKenzie BR, Miller TJ, Cyr S, Leggett WC (1994) Evidence for a domeshaped relationship between turbulence and larval fish ingestion rates. Limnol Oceanogr 39:1790-1799. [CrossRef]

Makareviciene P dr. V, Skorupskaitė V, Andrulevičiūtè V (2013) Biomass and Oil Production of Green Microalgae Scenedesmus sp. Using Different Nutrients and Growth. Environ Res Eng Manag 62: [CrossRef]

Makareviciene PDV, Andrulevičiūtė V, Skorupskaitė V, Kasperovičienė J (2011) Cultivation of Microalgae Chlorella sp. and Scenedesmus sp. as a Potentional Biofuel Feedstock. Environ Res Eng Manag 57:21-27

Mari X, Robert M (2008) Metal induced variations of TEP sticking properties in the southwestern lagoon of New Caledonia. Mar Chem 110:98-108. [CrossRef]

Marra J (1980) Vertical Mixing and Primary Production. In: Primary Productivity in the Sea. Springer US, Boston, MA, pp 121-137. [CrossRef]

Marshall JS, Huang Y (2010) Simulation of light-limited algae growth in homogeneous turbulence. Chem Eng Sci 65:3865-3875. [CrossRef]

Mata TM, Martins AA, Caetano NS (2010) Microalgae for biodiesel production and other applications: A review. Renew Sustain Energy Rev 14:217-232. [CrossRef] 
Moreno-Ostos E, Cruz-Pizarro L, Basanta A, George DG (2009) The influence of wind-induced mixing on the vertical distribution of buoyant and sinking phytoplankton species. Aquat Ecol 43:271-284. [CrossRef]

Myers JA, Curtis BS, Curtis WR (2013) Improving accuracy of cell and chromophore concentration measurements using optical density. BMC Biophys 6:4. [CrossRef]

Patil V, Tran K-Q, Giselrød HR (2008) Towards Sustainable Production of Biofuels from Microalgae. Int J Mol Sci 9:1188-1195. [CrossRef]

Peters F, Arin L, Marrasé C, et al (2006) Effects of small-scale turbulence on the growth of two diatoms of different size in a phosphoruslimited medium. J Mar Syst 61:134-148. [CrossRef]

Rhee Gull, Gotham IJ (1981) The effect of environmental factors on phytoplankton growth: Light and the interactions of light with nitrate limitation1. Limnol Oceanogr 26:649-659. [CrossRef]

Rokkan Iversen K, Primicerio R, Larsen A, et al (2010) Effects of small-scale turbulence on lower trophic levels under different nutrient conditions. J Plankton Res 32:197-208. [CrossRef]

Rothschild BJ, Osborn TR (1988) Small-scale turbulence and plankton contact rates. J Plankton Res 10:465-474. [CrossRef]

Rumyantseva A, Lucas N, Rippeth T, et al (2015) Ocean nutrient pathways associated with the passage of a storm. Global Biogeochem Cycles 29:1179-1189. [CrossRef]

Saiz E, Alcaraz M, Paffenhöfer G-A (1992) Effects of small-scale turbulence on feeding rate and gross-growth efficiency of three Acartia species (Copepoda: Calanoida). J Plankton Res 14:1085-1097. [CrossRef]

San L, Long T, Liu C (2017) Algal bioproductivity in turbulent water: An experimental study. Water 9:304. [CrossRef]

Sandnes JM, Ringstad T, Wenner D, et al (2006) Real-time monitoring and automatic density control of large-scale microalgal cultures using near infrared (NIR) optical density sensors. J Biotechnol 122:209-215. [CrossRef]

Schellenberg M, Matile P, Thomas H (1990) Breakdown of Chlorophyll in Chloroplasts of Senescent Barley Leaves Depends on ATP. J Plant Physiol 136:564-568. [CrossRef]

Schenk PM, Thomas-Hall SR, Stephens E, et al (2008) Second Generation Biofuels: High-Efficiency Microalgae for Biodiesel Production. BioEnergy Res 1:20-43. [CrossRef]

Schwartz W (1975) Janet R. Stein (Editor), Handbook of Phycological Methods, Culture Methods and Growth Measurements. XII, 448 S., 52 Abb., 44 Tab. Cambridge 1973: University Press, Ł 8.-. Z Allg Mikrobiol 15:216-216. [CrossRef]

Sforza E, Simionato D, Giacometti GM, et al (2012) Adjusted Light and Dark Cycles Can Optimize Photosynthetic Efficiency in Algae Growing in Photobioreactors. PLoS One 7:e38975. [CrossRef]
Shriwastav A, Thomas J, Bose P (2017) A comprehensive mechanistic model for simulating algal growth dynamics in photobioreactors. Bioresour Technol 233:7-14. [CrossRef]

Sivakumar, R; Rajendran S (2013) Growth measurement technique of microalgae. Curr Sci J 7:52-54.

Spolaore P, Joannis-Cassan C, Duran E, Isambert A (2006) Commercial applications of microalgae. J Biosci Bioeng 101:87-96. [CrossRef]

Subhash N, Wenzel O, Lichtenthaler HK (1999) Changes in blue-green and chlorophyll fluorescence emission and fluorescence ratios during senescence of tobacco plants. Remote Sens Environ 69:215-223. [CrossRef]

Sullivan JM, Swift E (2003) Effects of small-scale turbulence on net growth rate and size of ten species of marine dinoflagellates. J Phycol 39:8394. [CrossRef]

Terray EA, Donelan MA, Agrawal YC, et al (1996) Estimates of Kinetic Energy Dissipation under Breaking Waves. J Phys Oceanogr 26:792807. [CrossRef]

Thomas WH, Gibson CH (1990) Effects of small-scale turbulence on microalgae. J Appl Phycol 2:71-77. [CrossRef]

Toennies G, Gallant DL (1949) The relation between photometric turbidity and bacterial concentration. Growth 13:7-20.

Vanags J, Kunga L, Dubencovs K, et al (2015) The Effect of Shaking, CO2 Concentration and Light Intensity on Biomass Growth of Green Microalgae Desmodesmus communis. Environ Res Eng Manag 70: [CrossRef]

Wang H, Zhou Y, Xia K, et al (2016) Flow-disturbance considered simulation for algae growth in a river-lake system. Ecohydrology 9:601-609. [CrossRef]

Wang L, Min M, Li Y, et al (2010) Cultivation of Green Algae Chlorella sp. in Different Wastewaters from Municipal Wastewater Treatment Plant. Appl Biochem Biotechnol 162:1174-1186. [CrossRef]

Yentsch CS, Menzel DW (1963) A method for the determination of phytoplankton chlorophyll and phaeophytin by fluorescence. Deep Res Oceanogr Abstr 10:221-231. [CrossRef]

Zhao B, Zhang Y, Xiong K, et al (2011) Effect of cultivation mode on microalgal growth and CO2 fixation. Chem Eng Res Des 89:17581762. [CrossRef]

Zhong CH (2004) A Study on the Eutrophication of the Three Gorges Reservoir. Sichuan University, Chengdu, China

Zhou J, Qin B, Casenave C, et al (2015) Effects of wind wave turbulence on the phytoplankton community composition in large, shallow Lake Taihu. Environ Sci Pollut Res 22:12737-12746. [CrossRef]

Zhu L, Wang Z, Shu Q, et al (2013) Nutrient removal and biodiesel production by integration of freshwater algae cultivation with piggery wastewater treatment. Water Res 47:4294-4302. [CrossRef] 